\title{
Sustainability assessment, rating systems and historical buildings Case study: Rehabilitated construction in a university site
}

\author{
Somayeh Sadrykia ${ }^{1, a}$, Leila Medghalchi ${ }^{2}$ Mohammadjavad Mahdavinejad $^{3}$ \\ ${ }^{1} P h D$. Student, Faculty of Art and Architecture, Tarbiat Modares University, Tehran, Iran \\ Lecturer, Faculty of Architecture, Tabriz Islamic Art University, Tabriz, Iran, \\ ${ }^{2}$ Assistant Professor, Faculty of Architecture, Tabriz Islamic Art University, Tabriz, Iran, \\ ${ }^{3}$ Associate Professor, Faculty of Art and Architecture, Tarbiat Modares University, Tehran, Iran \\ somayeh.sadrykia@modares.ac.ir
}

\begin{abstract}
This paper explores the relationship between the indicators and different factors that "rating systems for green projects" concentrates on, and principles and factors considered in the rehabilitation of historical buildings. In recent years, different methods and systems concerned and improved for assessing environmental sustainability. LEED (Leadership in Energy and Environmental Design) and BREEAM (Building Research Establishment (BRE) Environmental Assessment Method) are two most commonly used rating systems, established in U.S and UK. These systems comprise some categories and different factors to achieve environmentally responsible design. Firstly, this study focuses on the list of rating systems indicators and criteria. Secondly this paper investigates a historical rehabilitated building in the site of Tabriz Art University, as a case study and has tried to compile its green design elements. Finally, this work intends to compare mentioned elements with indicators and factors of building rating systems. Findings of the study revealed that "Materials and Resources", "indoor environmental quality" and also "Sustainable Sites" ,the most significant indicator of rating systems, had major and important role in the rehabilitation of the building. Beyond this materials' life cycle was considerable in construction.

Keywords: Rating Systems, Materials Life cycle, Indicators, LEED, BREEAM, Rehabilitation
\end{abstract}

\section{Introduction}

The term sustainable development can be described as enhancing quality of life and thus allowing people to live in a healthy environment and improve social, economic and environmental conditions for present and future generations. Since the world commission on environment and development (WCED), entitled Our Common Future (1987), sustainable development has gained much attention in all nations and a report was published with a classic definition of sustainable development as: "Development meeting the needs of the present without compromising the ability of future generations to meet their own needs" [1].

The improving social, economic and environmental indicators of sustainable development are drawing attention to the construction industry, which is a globally emerging sector, and a highly active industry in both developed and developing countries [2].

In construction sector energy consumption, co2 emission, waste management, pollution, environmental impact and resources and materials depletion are considered for sustainable design and building sustainability. The importance of building assessment in reaching "sustainable design" and "green design" has led to the establishment of assessment methodologies which evaluate buildings environmental impact and predict and measure the success of a building or development against

\footnotetext{
${ }^{a}$ Corresponding author: somayeh.sadrykia@modares.ac.ir
}

sustainability criteria. "assessment methodologies were designed to calculate specific criteria such as thermal loads, energy or water consumption or life cycle impact of product manufacture"[3]. An appropriate and most common used assessment rating systems, such as LEED and BREEAM, makes a very useful framework for sustainable design which comprises different categories and issues and lead to rating of the different types of building. It seems that these categories and criteria can be used in assessing and evaluating historical buildings too.

So, the aim of this research is to study and investigate on the sustainability assessment and rating systems' categories and issues in one hand, and the green elements considered in the generation and rehabilitation of historical buildings, on the other hand, to conclude and outline the key joint and common elements, and categories. Hence the challenge that this study addresses is to answer two research questions:

Q1: Which one of LEED and BREEAM categories and credits are used and considered in historical and rehabilitated buildings' greening?

Q2: which one of the mentioned categories and issues have the most important role in the rehabilitated case of this study? 


\section{Building Assessment and Rating Systems}

In the early $1960 \mathrm{~s}$, concerns over the limitations of raw materials and energy resources, led to the development of the first exercises in life cycle assessment. So a number of methods and systems established and developed to assess and measure the success of building against environmental or sustainability criteria. These different assessment tools for the construction sector can be used in different design stages.

In the UK, Building Research Establishment (BRE) launched its Environmental Assessment Method (BREEAM) in 1990, which predict and measure the performance of building by calculating specific criteria [3]. In the US, Green building council established the Leadership in Energy and Environmental Design (LEED), in 1998 as a rating tool, with the same roots as BREEAM .After those different versions of LEED was launched and used. Beyond these two, some other similar sustainability assessment tools and methods launched in different area all over the world. Table 1.

Table 1. Examples of most common sustainability assessment methodologies and rating systems [3].

\begin{tabular}{|c|c|c|}
\hline Rating Systems & Country & Year \\
\hline $\begin{array}{c}\text { BREEAM } \\
\text { Building Research } \\
\text { Establishment (BRE) } \\
\text { Environmental Assessment } \\
\text { Method }\end{array}$ & Kingdom & 1990 \\
$\begin{array}{c}\text { LEED } \\
\text { Leadership in Energy and } \\
\text { Environmental Design }\end{array}$ & United State & 1998 \\
\hline Green Globes & Canada & 2000 \\
\hline Green Star & Australia & 2003 \\
\hline $\begin{array}{c}\text { NABERS } \\
\text { National Australian Building } \\
\text { Environmental Rating Scheme }\end{array}$ & Australia & 2000 \\
\hline $\begin{array}{c}\text { HK-BEAM } \\
\text { Hong Kong Building } \\
\text { Environmental Assessment } \\
\text { Method }\end{array}$ & China & 1996 \\
\hline $\begin{array}{c}\text { CASBEE } \\
\text { Comprehensive Assessment } \\
\text { System for Environmental } \\
\text { Efficiency }\end{array}$ & Japan & 2001 \\
\hline $\begin{array}{c}\text { HQE } \\
\text { Haute Qualite Environmentale }\end{array}$ & France & 2005 \\
\hline
\end{tabular}

\subsection{BREEAM}

In order to provide a method by which environmental impacts can be combined in a single measure, BRE developed BREEAM (Building Research Establishment Environmental Assessment Method). It designed and covered a variety of different scenarios as table 2 [3].

Table 2: Building types assessed by BREEAM

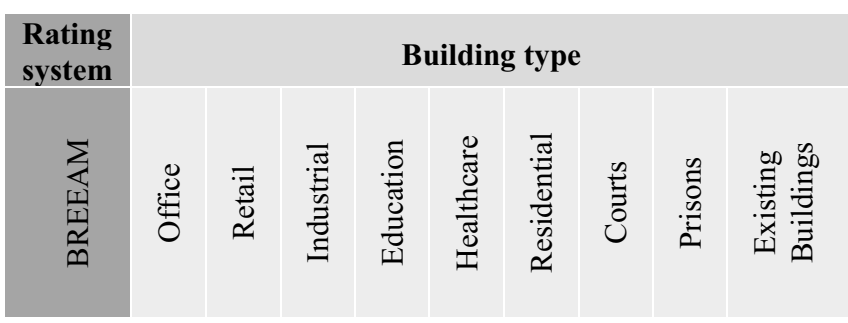

\subsubsection{Project Certification}

BREEAM sets the standard for best practice in sustainable building design, construction and operation and has become one of the most comprehensive and widely recognized measures of a building, environmental performance, which are set against established benchmarks, to evaluate a building's specification, design, construction and use. The measures used represent a broad range of categories and criteria from material, energy to ecology. They include aspects related to energy and water use, the internal environment (health and well-being), pollution, transport, materials, waste and management processes. BREEAM rating benchmarks is obvious in table 3 .

Table 3. BREEAM rating benchmarks [4]

\begin{tabular}{|l|l|}
\hline BREEAM Rating & Score (\%) \\
\hline Out standing & 85 \\
\hline Excellent & 70 \\
\hline Very Good & 55 \\
\hline Good & 45 \\
\hline Pas & 30 \\
\hline Unclassified & $<30$ \\
\hline
\end{tabular}

\subsubsection{Categories and criteria of BREEAM rating system}

Different categories and criteria, which BREEAM based on, are mentioned, in the Table 4. 
Table 4. Scoring and rating BREEAM assessed buildings(www.breeam.org)

\begin{tabular}{|c|c|}
\hline Categories & Issues (credits) \\
\hline Management & $\begin{array}{l}\text { Sustainable procurement } \\
\text { Responsible construction practices } \\
\text { Construction site impacts } \\
\text { Stakeholder participation } \\
\text { Life cycle cost and service life } \\
\text { planning }\end{array}$ \\
\hline $\begin{array}{l}\text { Health and well- } \\
\text { being }\end{array}$ & $\begin{array}{l}\text { Visual comfort } \\
\text { Indoor air quality } \\
\text { Thermal comfort } \\
\text { Water quality } \\
\text { Acoustic performance } \\
\text { Safety and security } \\
\end{array}$ \\
\hline Energy & $\begin{array}{l}\text { Reduction of emissions } \\
\text { Energy monitoring } \\
\text { External lighting } \\
\text { Low and zero carbon technologies } \\
\text { Energy efficient cold storage } \\
\text { Energy efficient transportation } \\
\text { systems } \\
\text { Energy efficient laboratory systems } \\
\text { Energy efficient equipment } \\
\text { Drying space }\end{array}$ \\
\hline Transport & $\begin{array}{l}\text { Public transport accessibility } \\
\text { Proximity to amenities } \\
\text { Cyclist facilities } \\
\text { Maximum car parking capacity } \\
\text { Travel plan }\end{array}$ \\
\hline Water & $\begin{array}{l}\text { Water consumption } \\
\text { Water monitoring } \\
\text { Water leak detection and prevention } \\
\text { Water efficient equipment }\end{array}$ \\
\hline Materials & $\begin{array}{l}\text { Life cycle impacts } \\
\text { Hard landscaping and boundary } \\
\text { protection } \\
\text { Responsible sourcing of materials } \\
\text { Insulation } \\
\text { Designing for robustness } \\
\text { Reuse of faced and façade and } \\
\text { structure }\end{array}$ \\
\hline Waste & $\begin{array}{l}\text { Construction waste management } \\
\text { Recycled aggregates } \\
\text { Operational waste } \\
\text { Speculative floor and ceiling finishes }\end{array}$ \\
\hline $\begin{array}{l}\text { Land Use and } \\
\text { Ecology }\end{array}$ & $\begin{array}{l}\text { Site selection } \\
\text { Ecological value of site and } \\
\text { protection of ecological features } \\
\text { Mitigating ecological impact } \\
\text { Enhancing site ecology } \\
\text { Long term impact on biodiversity }\end{array}$ \\
\hline Pollution & $\begin{array}{l}\text { Impact of refrigerants } \\
\text { NOx emissions } \\
\text { Surface water run off } \\
\text { Reduction of night time light } \\
\text { pollution } \\
\text { Noise attenuation }\end{array}$ \\
\hline $\begin{array}{l}\text { Innovation } \\
\text { (additional) }\end{array}$ & \\
\hline
\end{tabular}

\subsection{LEED}

LEED (Leadership in Energy and Environmental Design) is a certification program which is intended to define high quality, ecological building methods for more environmentally-friendly and profitable buildings [5]. LEED has the same roots as BREEAM but is administered by the US Green Building Council. Although the headings are different to BREEAM the issue covered are similar.

There are versions of LEED for New Construction commercial buildings (LEED NC), Existing buildings, Commercial Interiors, Core and Shell and Retail. LEED for homes, which was launched in 2008, is designed for application to housing developments of all sizes, ranging from individual houses to high density apartment schemes. Fig1. There is also a version for Neighborhood Development that was launched in 2009 and has similarities to the BREEAM [3].

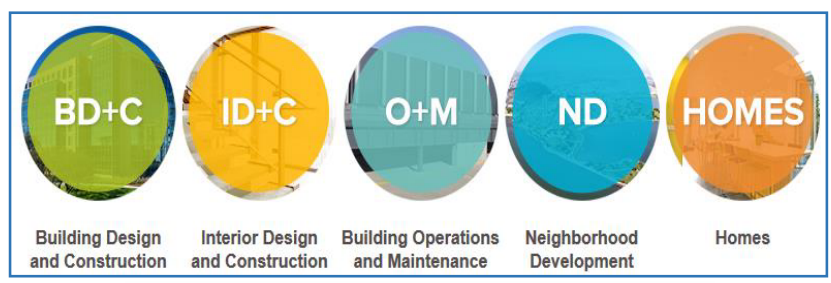

LEED is flexible enough to apply to all project types.

Fig1. Building types in LEED (http://www.usgbc.org/leed)

\subsubsection{Project Certification}

LEED covers all ecological and socio-cultural aspects of sustainability. It focuses mainly on energy and water efficiency, the reduction of $\operatorname{co} 2$ emissions, a healthy and comfortable indoor climate and conservation of resources, assesses the building operations as well as the quality of site [6].

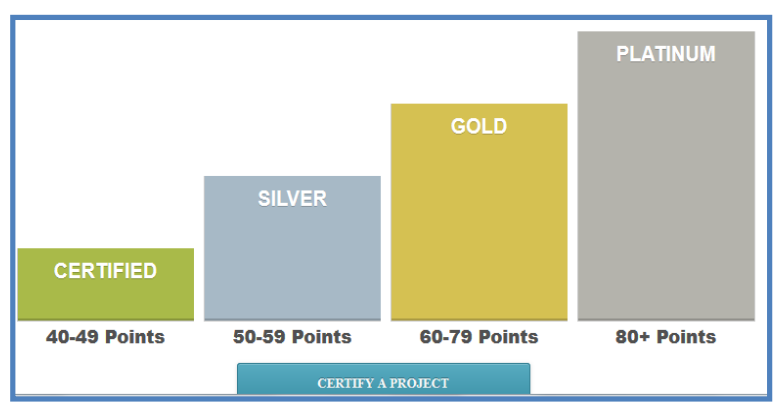

Fig 2. Ratings are awarded on a scale from certified to platinum through silver and gold (http://www.usgbc.org/leed)

The LEED certification is based on a point system, points are awarded for the fulfilment of individual credits. Fig2. The system divides the predetermined credits into seven categories. The weighting of the categories differs slightly between the rating systems. Apart from the minimum number of points required for the level of LEED certification aimed at, there are so called prerequisites which must be met [6]. 
The maximum number of points attainable depends on the project type for e.g., LEED-NC (new construction) the maximum points achievable is 69 while for LEED-EB (existing building) it is 92 [7]. In relation to this, the certification levels LEED certification, silver, gold, and platinum are awarded [5]. Certification is based on an assessment on the completed building.

\subsubsection{Categories and criteria of LEED rating system}

Different categories and criteria, which LEED based on, are mentioned, in Table 5.

Table 5. Scoring and rating LEED assessed buildings.

LEED 2009 for New Construction and Major Renovations Project Checklist [10], [11].

\begin{tabular}{|c|c|}
\hline Categories & Issues (credits) \\
\hline Sustainable Sites & $\begin{array}{l}\text { Construction Activity Pollution } \\
\text { Prevention (Prerequisite 1) } \\
\text { Site Selection } \\
\text { Development Density and Community } \\
\text { Connectivity } \\
\text { Brownfield Redevelopment } \\
\text { Alternative Transportation } \\
\text { Site Development } \\
\text { Storm-water Design-Quantity Control } \\
\text { Heat Island Effect-Non-roof } \\
\text { Light Pollution Reduction }\end{array}$ \\
\hline Water Efficiency & $\begin{array}{l}\text { Water Use Reduction (Prerequisite 1) } \\
\text { Water Efficient Landscaping } \\
\text { Innovative Wastewater Technologies } \\
\text { Water Use Reduction }\end{array}$ \\
\hline $\begin{array}{l}\text { Energy and } \\
\text { Atmosphere }\end{array}$ & $\begin{array}{l}\text { Fundamental Commissioning of Building } \\
\text { Energy System (Prerequisite 1) } \\
\text { Minimum Energy Performance } \\
\text { (Prerequisite 2) } \\
\text { Fundamental Refrigerant Management } \\
\text { (Prerequisite 3) } \\
\text { Optimize Energy Performance } \\
\text { On-site Renewable Energy } \\
\text { Enhanced Commissioning } \\
\text { Enhanced Refrigerant Management } \\
\text { Measurement and Verification } \\
\text { Green Power }\end{array}$ \\
\hline $\begin{array}{l}\text { Materials and } \\
\text { Resources }\end{array}$ & $\begin{array}{l}\text { Storage and Collection of Recyclables } \\
\text { (Prerequisite 1) } \\
\text { Building Reuse } \\
\text { Construction Waste Management } \\
\text { Materials Reuse } \\
\text { Recycled Content } \\
\text { Regional Materials } \\
\text { Rapidly Renewable Materials } \\
\text { Certified Wood }\end{array}$ \\
\hline
\end{tabular}

\begin{tabular}{|c|c|}
\hline $\begin{array}{l}\text { Indoor } \\
\text { Environmental } \\
\text { Quality }\end{array}$ & $\begin{array}{l}\text { Minimum Indoor Air Quality } \\
\text { Performance (Prerequisite 1) } \\
\text { Environmental Tobacco Smoke (ETS) } \\
\text { Control (Prerequisite 2) } \\
\text { Outdoor Air Delivery Monitoring } \\
\text { Increased Ventilation } \\
\text { Construction Indoor Air Quality } \\
\text { Management Plan } \\
\text { Low-Emitting Materials } \\
\text { Indoor Chemical and Pollutant Source } \\
\text { Control } \\
\text { Controllability of Systems } \\
\text { Thermal Comfort-Design } \\
\text { Daylight and Views }\end{array}$ \\
\hline $\begin{array}{l}\text { Innovation in } \\
\text { Design }\end{array}$ & $\begin{array}{l}\text { Innovation in Design } \\
\text { LEED Accredited Professional }\end{array}$ \\
\hline Regional Priority & Regional Priority \\
\hline \multicolumn{2}{|l|}{ Possible Points: 110} \\
\hline $\begin{array}{l}100 \text { base points; } 6 \mathrm{p} \\
\text { Priority points } \\
\text { Certified } \\
\text { Silver } \\
\text { Gold } \\
\text { Platinum }\end{array}$ & $\begin{array}{l}\text { sible Innovation in Design and } 4 \text { Regional } \\
40-49 \text { points } \\
50-59 \text { points } \\
60-79 \text { points } \\
80 \text { points and above }\end{array}$ \\
\hline
\end{tabular}

\section{Historic Preservation}

Human connection to nature, community, and place is a necessary element of healthy living and the ability to achieve sustainability. Connectivity to nature is now defined as bio philia and widely celebrated in sustainable design. Built responses to the natural world must vary by climatic zone and conditions unique to each area. So, too, must the memory of place, which requires that buildings and heritage areas from past generations and cultures be retained to avoid creating communities so lacking in personality that it is impossible to identify geographic location without signage [8].

The act of preserving a site, a building, or a community is a gesture of respect for past decisions and a gift to future generations who may enjoy or be curious about the physical manifestation of different times and cultures as Randall Mason said: "Nearly any way the effects are measured, be they direct or indirect, historic preservation tends to yield significant benefits to the economy." (Ibid) By the way, in this research, one building of an educational complex (that was rehabilitated) is selected as a case study and intended to compare mentioned elements with indicators and factors of building rating systems such as LEED.Table 6 
Table 6 : Rating Systems Categories Comparing with Green Design Elements

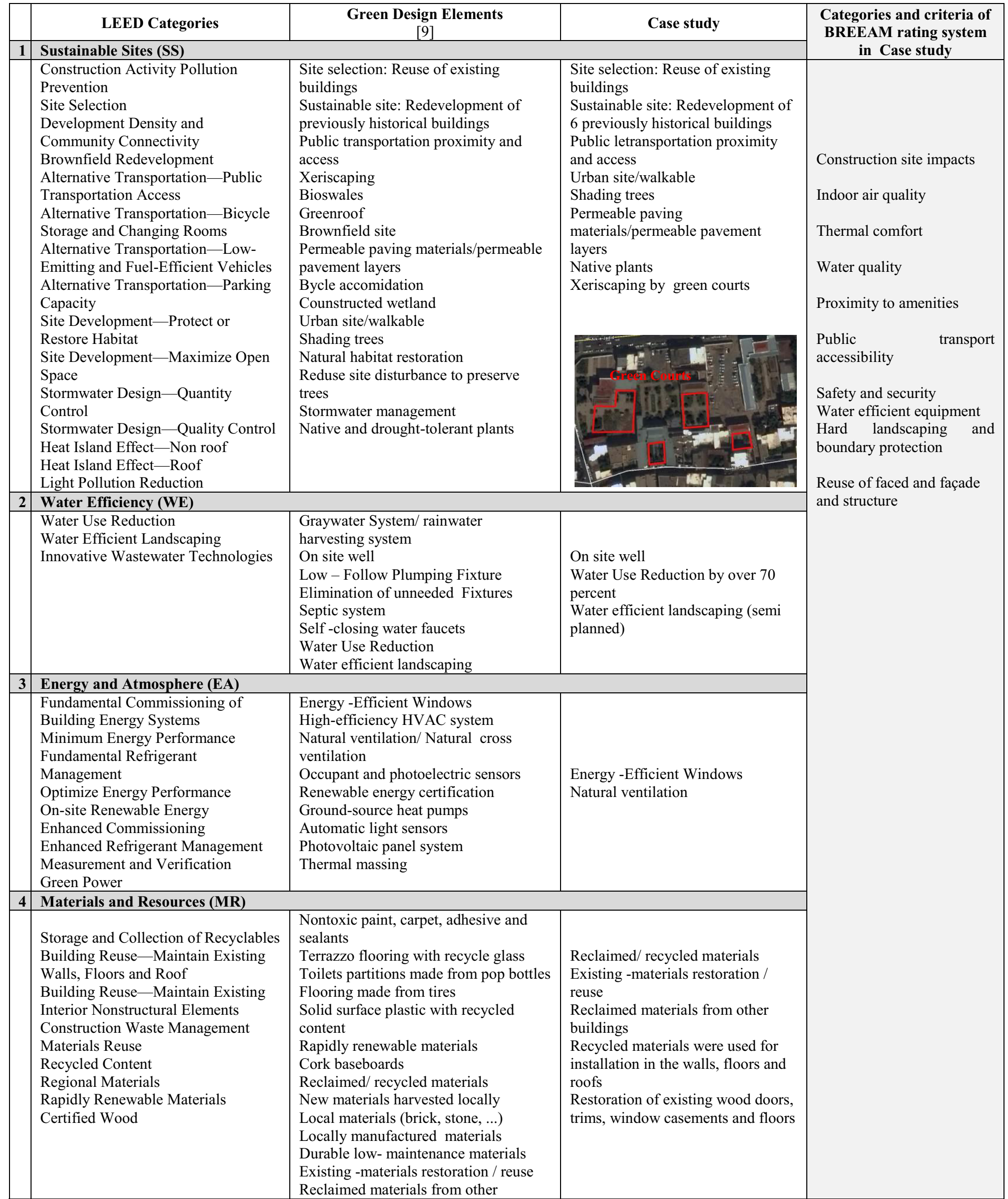




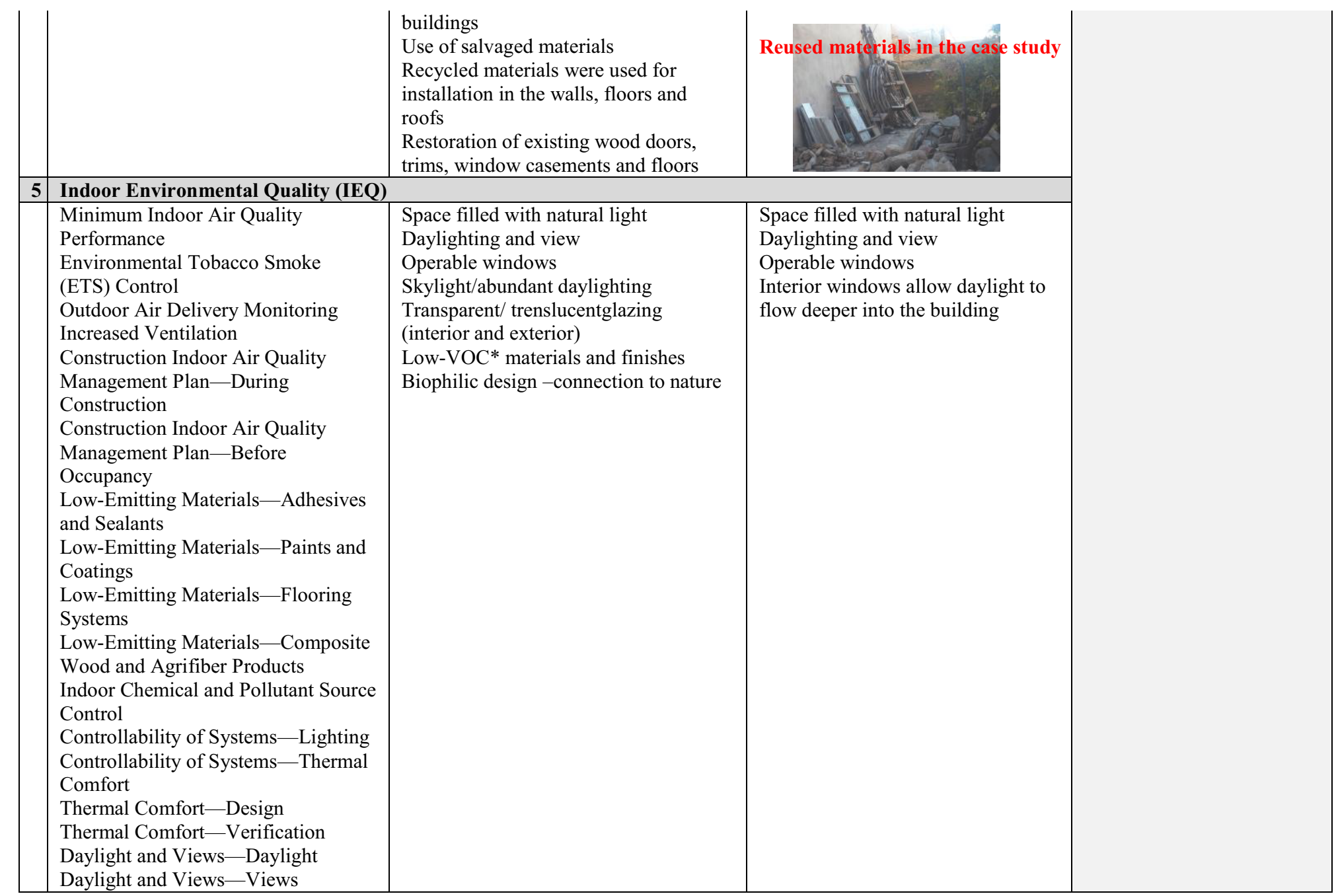

* Volatile organic compounds (VOCs) are organic chemicals that have a high vapor pressure at ordinary room temperature. Their high vapor pressure results from a low boiling point, which causes large numbers of molecules to evaporate or sublimate from the liquid or solid form of the compound and enter the surrounding air.

\section{Case study}

Name: Ganjeh-i-zadeh House

Location: Maghsoudieh Street .Tabriz. IRAN.

This house is renovated in their original design to host the Faculty of Architecture and Urban Design. Its eastern section has three floors and a vaulted basement .Fig4. The architecture layout of the western component of this three- story building is extroverted. The vaulted basemen housed the kitchen, storage and cistern. Its ground floor on the east and west side has a staircase, one columned ivan and six rooms. The largest ceremonial hall of this structure is located the first floor with span of over $7 \mathrm{~m}$. covered with wooden trusses [9].

This house is renovated in their original design to host the Faculty of Architecture and Urban Design. Its eastern section has three floors and a vaulted basement .Fig4. The architecture layout of the western component of this three- story building is extroverted. The vaulted basemen housed the kitchen, storage and cistern. Its ground floor on the east and west side has a staircase, one columned ivan and six rooms. The largest ceremonial hall of this structure is located the first floor with span of over $7 \mathrm{~m}$ covered with wooden trusses"(IBid).

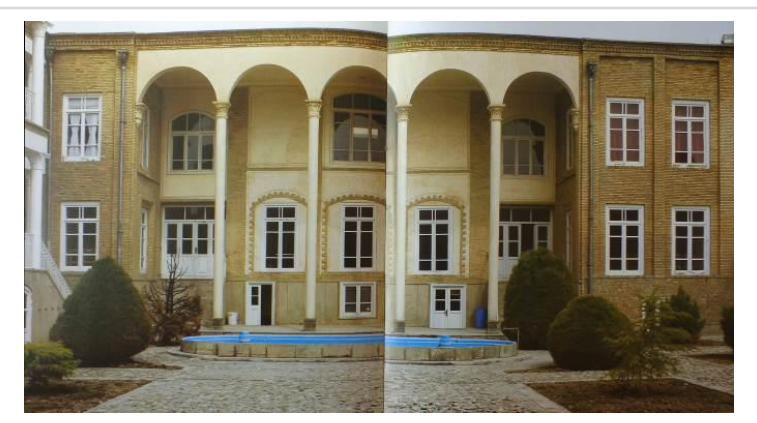

Fig 3. The eastern part of building - built in the Qajar period 


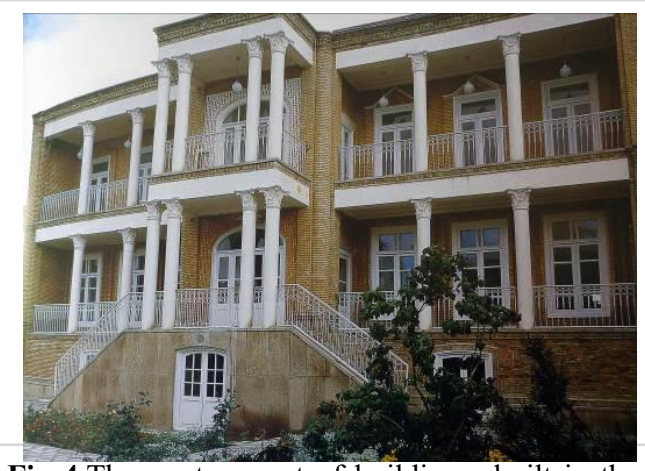

Fig 4. The western part of building - built in the Pahlavi period

\subsection{Case study Analysing}

\section{Site Utilization and sustainable site}

- Reuse of existing buildings, redevelopment of 6 previously historical buildings

- Xeriscaping: plantings in courtyards to utilize plant • schemes those are drought-tolerant and native to an area.

- The L-shape of the building was intentionally chosen to create a courtyard for community gathering.

- South-facing building sunspace achieves maximum solar exposure during the winter and during the summer is • protected by porch and trees.Fig5.

\section{Alternative Transportation}

- The building site is close to public transportation systems (including bus and taxi stations).Fig5.

- There are different accommodations near the complex for students' daily needs that cause less traffic (walkability).

\section{Materials and Resources (MR)}

- Durable, long-lived materials and composite durability of a construction system such as a masonry wall are common in many historic buildings.

Material selection was influenced by local availability. Brick products, stone all came near the project.

- The design strategy sought the lowest possible environmental impact by seeking salvaged materials (like unused brick and wood), and new materials from local sources.

- The design combines visible celebration of historic elements and reuse of materials to intentionally establish a connection to the past.

Reused materials include salvaged wooden trusses that were removed from several floors to support the ceiling (reuse of salvaged building components).

\section{Indoor Environmental Quality (IEQ)}

\section{Daylighting.}

Interior windows allow daylight to flow deeper into the building: During the day, most of the occupied areas of the building are flooded with natural light from the window openings.

- Stablished skylights bring natural light to the interior of the building.Fig6.

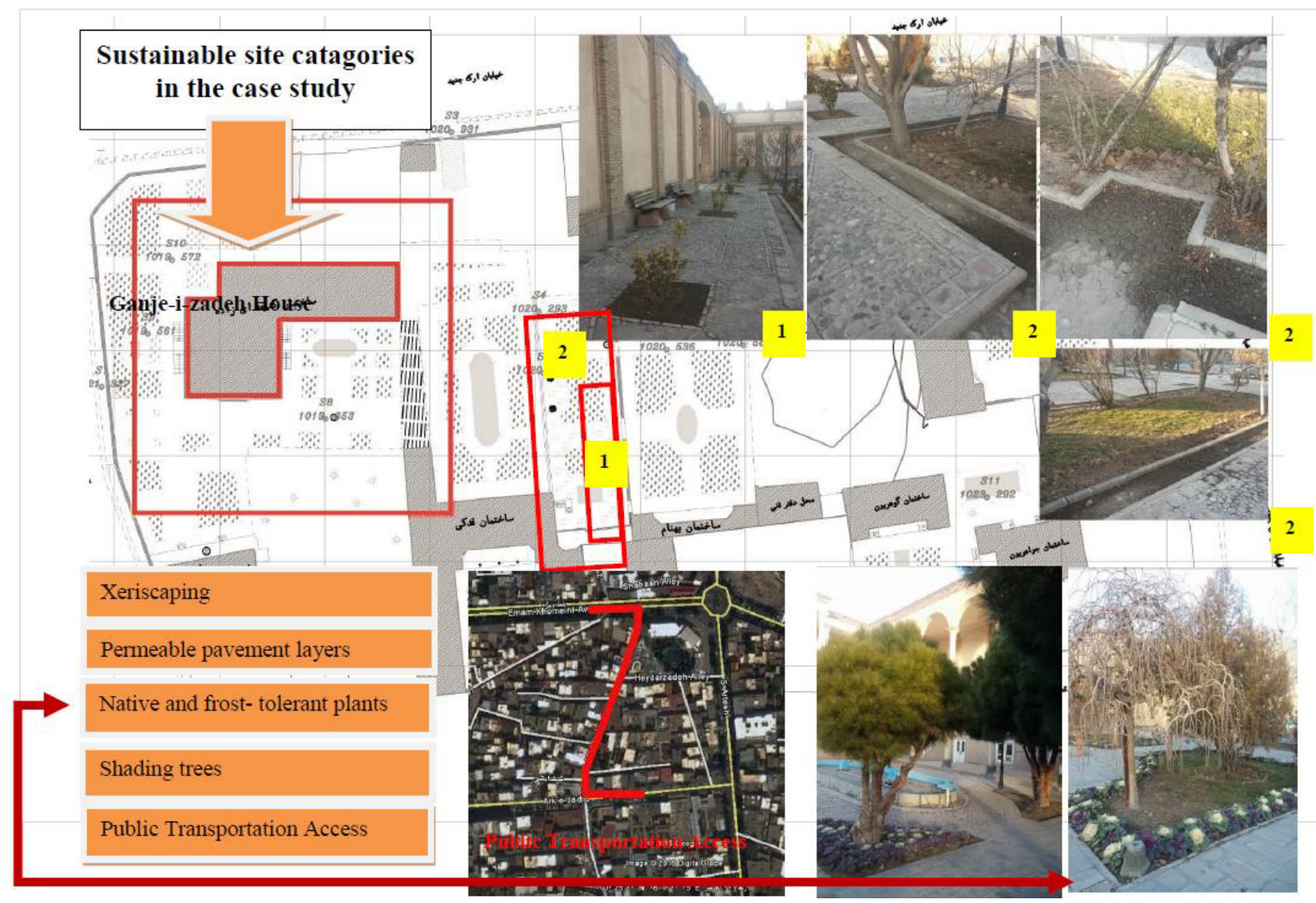

Fig5 .Sustainable site catagories in the case study 


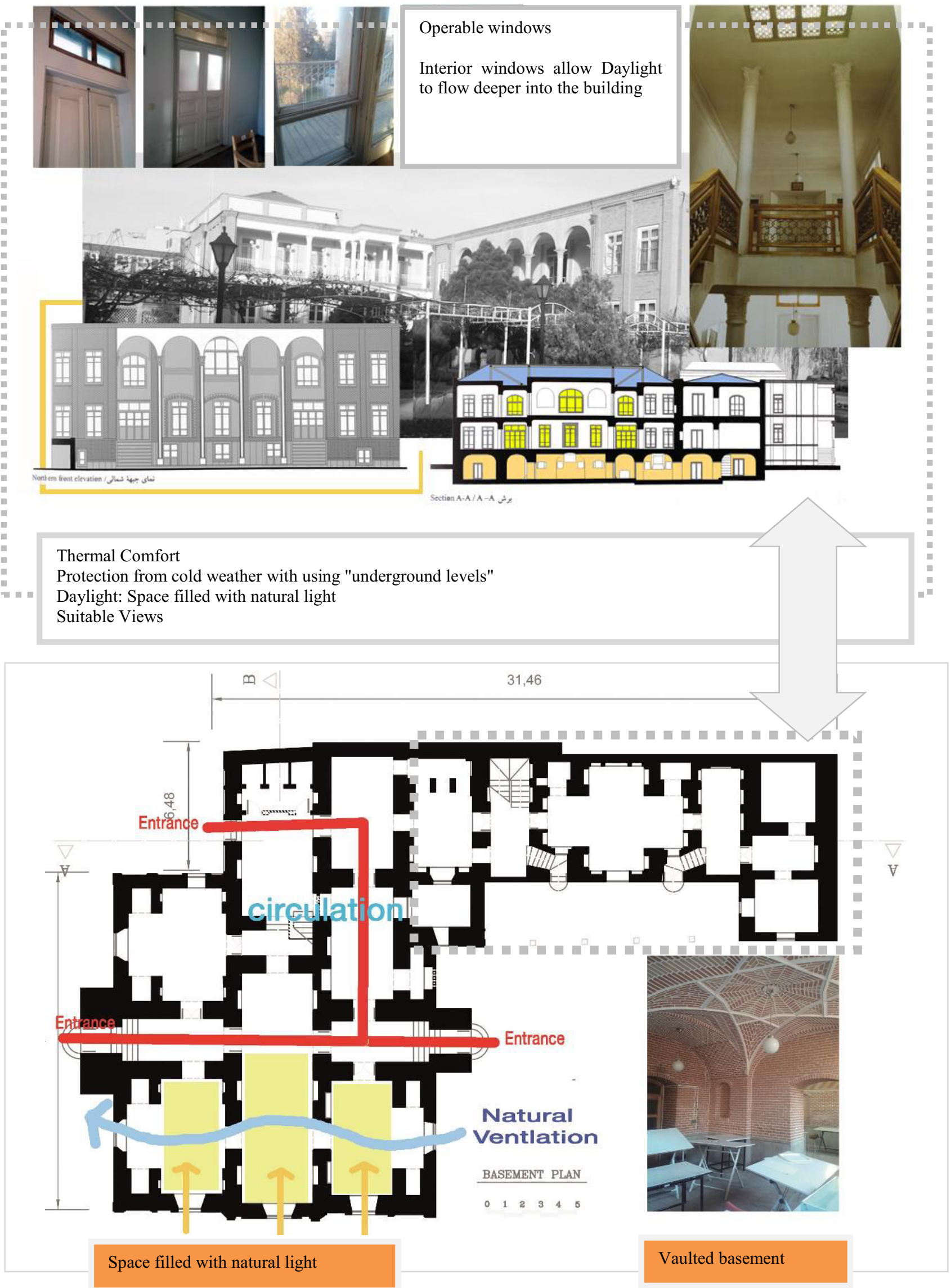

Fig6. Indoor Environmental Quality (IEQ) in the case study 


\section{Conclusions and Future Perspectives}

This paper reviewed rating systems concepts for green projects, with a particular focus on its applicability and uptake within historic preservation. In addition, an exploratory study was carried out to studying attentively one of the rehabilitated constructions in the university site.

Although some researches investigations provide some insight into the rating systems concepts in preservation historical buildings, there is a need for continued research on the green elements (that follows rating systems concepts) implementation in rehabilitation and construction process.

This research outlines the major challenges which face assembling a survey in one type of the buildings. That is, rehabilitated and there is often a need to draw on knowledge from the past. In considering these issues, it is important to remember that this paper does not provide a conclusive implementation approach. This review provides comparing the rating systems issues with the preserved construction to find out the potentials of this type of buildings to be a sustainable.

As shown in this paper and according to last table and analysis of case study, rating systems needs perspicuous sub- criteria for buildings evaluation. Some of these measurable sub-criteria were used in different projects as Green Elements. So, these measurable sub-criteria were gathered and analyzed in a historical rehabilitated building as a case study.

In an immensely complex topic, one basis truth about historical buildings is that these buildings originally contain much aspects of sustainability, In spite of that; in some rehabilitation processes some of the sustainable aspects may be lost.

Finally, this paper reveals main parts of green elements that can be intentioned in historical preservation. These elements can be employed by designers in rehabilitation projects. An Investigations on the case, also indicates that, some specific categories and criteria of rating systems such as: "indoor environmental quality", "materials and resources" and "Sustainable Sites" has more effective and considerable impact on the sustainable rehabilitation.

\section{References}

1. Brundtland report, World commission on environment and development. Report of the United Nations, (1987)

2. O. Ortiz, C. Francesc, S. Guido, Construction and Building Materials, 23, 28-39 (2009)

3. P. Appleby, Integrated Sustainable Design of Buildings (London: Earthscan, 2011)

4. BREEAM, Pre-assessment estimator, (2011) [Online]. Available: http://www.breeam.org/page.jsp?id=87.

5. A. Basnet, BREEAM \& LEED: A study of materials and their life cycle impact,(2011)

6. T. Ebert, N. Ebig, G. Haurer, Green Building Certification Systems, (2011)
7. W. Houlihan, An Analysis of the Performance of Certification Schemes in the Hotel Sector in terms of CO2 Emissions Reduction, (2009)

8. j. Carroon, Sustainable preservation: Greening Existing Buildings, (2010)

9. M.A. Kaynejad, M.R. Shirazi, The Traditional Houses of Tabriz, (2010).

10. LEED 2009 for new construction and major renovations. (2008). Washington, D.C.: U.S. Green Building Council

11. U.S.G.B.C. 2009. Green Building Design and Construction, LEED Reference Guide for Green Building Design \& Construction, USA, i-xiv, 335-400.

12. N. Lazarus, Bed ZED Toolkit part 1: A guide to construction materials for carbon neutral developments, (2002). 